\title{
Glucocorticoid receptor beta increases migration of human bladder cancer cells
}

\author{
Lucien McBeth ${ }^{1}$, Assumpta C. Nwaneri ${ }^{1}$, Maria Grabnar ${ }^{1}$, Jonathan Demeter ${ }^{1}$, \\ Andrea Nestor-Kalinoski ${ }^{2}$, Terry D. Hinds, Jr. ${ }^{1}$ \\ ${ }^{1}$ Center for Hypertension and Personalized Medicine, Department of Physiology and Pharmacology, University of Toledo \\ College of Medicine, Toledo, $\mathrm{OH} 43614$, USA \\ ${ }^{2}$ Advanced Microscopy and Imaging Center, Department of Surgery, University of Toledo College of Medicine, Toledo, OH \\ 43614, USA
}

Correspondence to: Terry D. Hinds, e-mail: Terry.Hinds@utoledo.edu

Keywords: glucocorticoid receptor, GR, GR alpha, GR beta, glucocorticoids

Received: January 28, 2016

Accepted: March 14, 2016

Published: March 27, 2016

\section{ABSTRACT}

Bladder cancer is observed worldwide having been associated with a host of environmental and lifestyle risk factors. Recent investigations on anti-inflammatory glucocorticoid signaling point to a pathway that may impact bladder cancer. Here we show an inverse effect on the glucocorticoid receptor (GR) isoform signaling that may lead to bladder cancer. We found similar GRa expression levels in the transitional uroepithelial cancer cell lines T24 and UMUC-3. However, the T24 cells showed a significant $(p<0.05)$ increased expression of GRß compared to UMUC-3, which also correlated with higher migration rates. Knockdown of GRß in the T24 cells resulted in a decreased migration rate. Mutational analysis of the $3^{\prime}$ untranslated region (UTR) of human GR $\beta$ revealed that miR144 might positively regulate expression. Indeed, overexpression of miR144 increased GR $\beta$ by 3.8 fold. In addition, miR144 and GR $\beta$ were upregulated during migration. We used a peptide nucleic acid conjugated to a cell penetrating-peptide (Sweet-P) to block the binding site for miR144 in the 3'UTR of GR $\beta$. Sweet-P effectively prevented miR144 actions and decreased GR $\beta$ expression, as well as the migration of the T24 human bladder cancer cells. Therefore, GR $\beta$ may have a significant role in bladder cancer, and possibly serve as a therapeutic target for the disease.

\section{INTRODUCTION}

Bladder cancer was the fourth most prevalent cancer in men, and fifth overall in 2015 [1]. Recently, glucocorticoids (GCs) have been used in bladder cancer for their protective properties against the toxic effects of chemotherapy [2]. GCs may cause resistance to cisplatin, which is a treatment commonly used for bladder cancer $[3,4]$. The GC receptor (GR) is expressed as different isoforms, GR $\alpha$ and GR $\beta$, which are a result of alternative splicing of a single gene [5-9]. GCs bind and activate the ligand-binding GR isoform, GR $\alpha$, which is a transcription factor that increases genes involved in cell cycle arrest and apoptosis [10-14]. GR $\beta$ lacks the ligand-binding domain for GCs [7, 9], and has been shown to be inhibitory to $\mathrm{GR} \alpha[7,8,15-17]$. A higher total GR expression has been correlated with a better prognosis in bladder cancer [3, 18]. However, the specific roles of GR $\alpha$ or GR $\beta$ in bladder cancer are unknown.
Recent work has shown a conundrum, in that GCs can suppress bladder cancer invasion, but also induce proliferation $[18,19]$. GCs are commonly used to inhibit growth in hematological cancers [20] and solid tumors [21]. Long-term GC treatment can increase the risk of bladder cancer, possibly through immunosuppression $[2,4]$, or by causing GC resistance through elevated $\operatorname{GR} \beta[4,9]$. The later remains to be elucidated. We have recently shown that GR $\beta$ can suppress the phosphatase and tensin homolog deleted on chromosome 10 (PTEN) expression and increase Akt1 guided proliferation [8]. Furthermore, GR $\beta$ has been shown to be involved in the migratory process of astrocytes and the development of glioblastoma [22]. Longui et al. showed that the effectiveness of GCs in patients was reduced with a lower GR $\alpha / G R \beta$ ratio [20]. Factors that regulate the expression of GR $\alpha$ or GR $\beta$ may influence the response to $\mathrm{GCs}$, and possibly mediate growth. GC resistance in sepsis has been shown to be affected by 
microRNA 124 (miR124), which down-regulated GR $\alpha$, causing increased immune cell growth [23].

It has been previously demonstrated that a naturally occurring mutation in the AUUA motif of the $3^{\prime}$ untranslated region (UTR) of GR $\alpha$ and GR $\beta$ results in increased mRNA stability and protein expression [24]. Targeting of the 3' UTR of genes by miRNAs may alter mRNA stability, which has been recently recognized to be involved in processes that regulate cancer development or progression [25-27]. Some miRNAs have been proposed as biomarkers to detect and predict the severity of bladder cancer [28-31]. The miRNAs that may regulate bladder cancer proliferation may be of importance, which was shown by miR125b targeting of the E2F3 transcription factor [32], a tumor suppressor that regulates the cell cycle. Furthermore, miR145 and miR133a decreased bladder cancer aggressiveness by targeting fascin actinbundling protein 1 (FSCN1) [33], which binds $\beta$-catenin to increase motility and invasion. Higher-grade bladder tumors have been shown to express elevated miR144 [34], which has also been shown to promote cell proliferation in nasopharyngeal carcinoma [35]. However, the involvement of miRNAs and their regulation of GR $\alpha$ or GR $\beta$ in bladder cancer development or progression are unknown.

In this investigation, we show that GR $\beta$ enhanced migration of human bladder cancer cells. We found three potential miRNA target sites in the $3^{\prime}$ UTR of human GR $\beta$ and show that miR144 positively affected human GR $\beta$ expression. Additionally, we show that blocking the binding site of miR144 in the 3' UTR of human GR $\beta$ inhibited expression, and, as a result, decreased migration of bladder cancer cells.

\section{RESULTS}

\section{GR $\beta$ \& GR $\alpha$ in human bladder cancer cells}

We have previously shown that GR $\beta$ is involved in regulating cellular pathways that are known to be involved in cancer [8]. However, the analysis was performed in noncancerous mouse fibroblast and 3T3-L1 cells. To examine the two GR isoforms in human bladder cancer, we assayed their expression in two transitional uroepothelial cancer cell lines, UMUC3 and T24. As shown by immunofluorescence staining and mRNA expression, we found that the T24 cell line had a higher expression of GR $\beta$ compared to the UMUC-3 (Figure 1A and 1B). GR $\alpha$ had similar levels by immunofluorescence and mRNA in the T24 cells. To determine if human bladder cancer cells that have higher GR $\beta$ expression are more migratory, we conducted a wound-healing migration assay. The T24 cells with higher GR $\beta$ expression had a significantly (ANOVA $p<0.0001$ ) faster migration compared to the UMUC-3 (Figure 1C and 1D). To show the effect of GR $\beta$ in the T24 cell line we established a stable cell line with an shRNA lentivirus targeting human GR $\beta$ (Figure 2A).
The knockdown of GR $\beta$ expression in the T24 cells (64\% reduction) (Figure 2B) resulted in a significant (ANOVA: $p<0.001$ ) decrease in migration (Figure 2C).

\section{The effect of insulin and dexamethasone on GRß \& GR $\alpha$ in human bladder cancer cells}

We have previously shown that insulin increased GR $\beta$ mRNA and protein expression in cells $[7,8]$ and livers of mice [7]. To determine the effect of insulin or dexamethasone (Dex) on GR isoform localization and expression, we treated the T24 and UMUC-3 bladder cancer cells for 30 minutes and labeled with human GR $\alpha$ or GR $\beta$ antibodies for immunofluorescence staining. Insulin treatment significantly increased GR $\beta$ expression in the T24 $(p<0.01)$ and UMUC-3 $(p<0.0001)$ cells (Figure 3A and $3 \mathrm{C}$ ). However, there was no difference observed in GR $\beta$ expression or localization in the human bladder cancer cells with Dex treatment, even though we have previously shown that GCs increased GR $\beta$ in normal mouse cells [7]. As for localization, GR $\beta$ was higher in the nucleus in the UMUC-3 with insulin, but not with Dex. There was no change in GR $\beta$ localization with insulin or Dex in the T24 cells. The GR $\alpha$ expression was significantly decreased $(p<0.001)$ by insulin in the T24 cells, but no effect was observed in the UMUC-3 (Figure 3B and 3D). Dex treatment increased GR $\alpha$ protein in both cell lines, as well as translocation from the cytoplasm (control) to the nucleus (Dex). These results may indicate a pro-growth pathway that involves the induction of GR $\beta$ and inhibition of GR $\alpha$ for proliferation or migration.

\section{GR $\alpha$ controlled gene transcription in human bladder cancer cells}

The role of the GR isoforms in human bladder cancer is unknown, especially the gene regulator activity of GR $\alpha$. To determine the GR $\alpha$-induced gene activity in human bladder cancer cells, we treated the T24 and UMUC-3 cells with Dex for 2 hours in hormone-free dialyzed serum. To test genes that are directly regulated by GR $\alpha$, we measured mRNA expression of known controlled genes FK506 binding protein 51 (FKBP51), glucocorticoid-induced leucine zipper (GILZ), and p21 (Figure 4). The UMUC3 cell line was more responsive to the Dex treatment on FKBP51, GILZ and p21 mRNA expression, likely due to the lower expression of GR $\beta$ leading to less GR $\alpha$ inhibition. The VEGFA expression was not different in the T24 cells, but was significantly $(p<0.01)$ deceased by Dex treatment in the UMUC-3 cells. The GR $\alpha$ expression was significantly $(p<0.05)$ lower in the T24 cells, but Dex treatment did not change the mRNA expression in UMUC-3 or T24 cells. The GR $\beta$ mRNA expression did not change with Dex treatments. However, it should be noted that the levels of GR $\beta$ and GR $\alpha$ mRNA are different than in Figure 1B, which is mostly likely due to the use of hormone-free serum for the glucocorticoid treatment. 


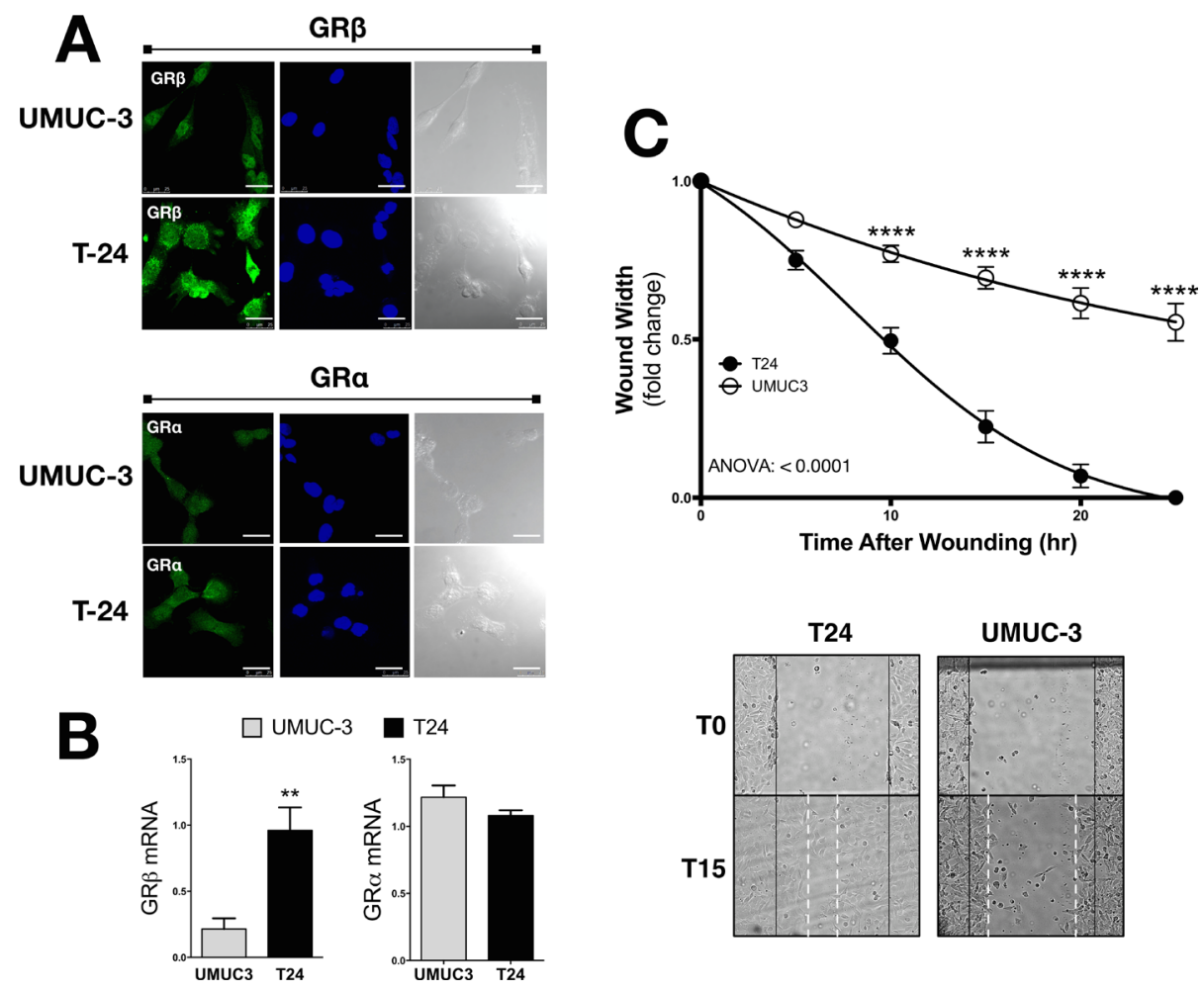

Figure 1: GR $\beta$ and GR $\alpha$ expression and migration in UMUC3 and T24 human bladder cancer cells. GR $\beta$ and GR $\alpha$ expression was measured by immunoflourescence (A). Secondary antibodies (labeling GR $\alpha$ or GR $\beta$ ) are shown in green, DAPI (nuclei labeling) are shown in blue, and a bright field images are shown in gray (scale bar $=25 \mu \mathrm{m}$ ). GR $\beta$ and GR $\alpha$ mRA expression measured by Real-Time PCR $(\mathbf{B}) .{ }^{*} p<0.05 ; * * p<0.01$ (versus UMUC3) ( \pm S.E.; $n=3$ ). Migration was measured in UMUC3 and T24 cells at 5, 10 , 15,20 , and 25 hours post wounding as the fold-changed wound width remaining $(\mathbf{C})$. Images of the migration assay at 0 and 15 hours post wounding, with wound edges marked at T0 (black solid line) and T15 (white dashed line). ANOVA $p<0.0001$; Bonferoni comparisons $* * * * p<0.0001$ (versus UMUC3) $( \pm$ S.E.; $n=6)$.
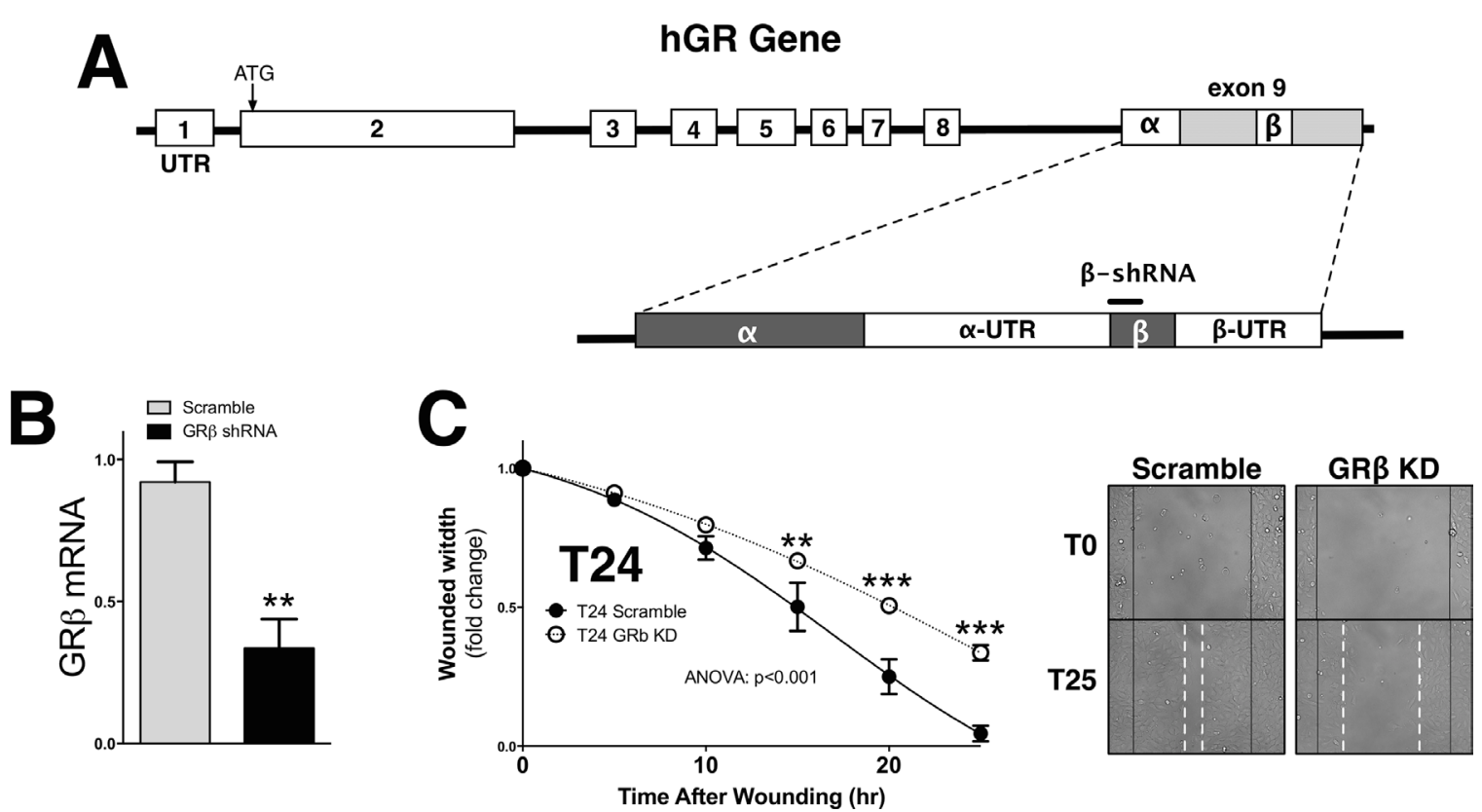

Figure 2: Knockdown of GRß reduces migration of human bladder cancer cells. Schematic of the the human GR gene to show the shRNA target site for GR $\beta$ (A). Knockdown of GR $\beta$ was confirmed by Real-Time PCR (B). ** $p<0.01$ (versus T24 Scramble) $( \pm$ S.E.; $n=3)$. Migration was measured in the T24 Scramble and T24 GR $\beta$ shRNA cells at 5, 10, 15, 20, and 25 hours post wounding $(\mathbf{C})$. Images of the migration assay at 0 and 25 hours post wounding are shown, with wound edges marked at T0 (black solid line) and T15 (white dashed line). ANOVA $p<0.001$; Bonferoni comparisons $* * p<0.01 ; * * p<0.001$. (versus T24 Scramble) $( \pm$ S.E.; $n=6)$. 

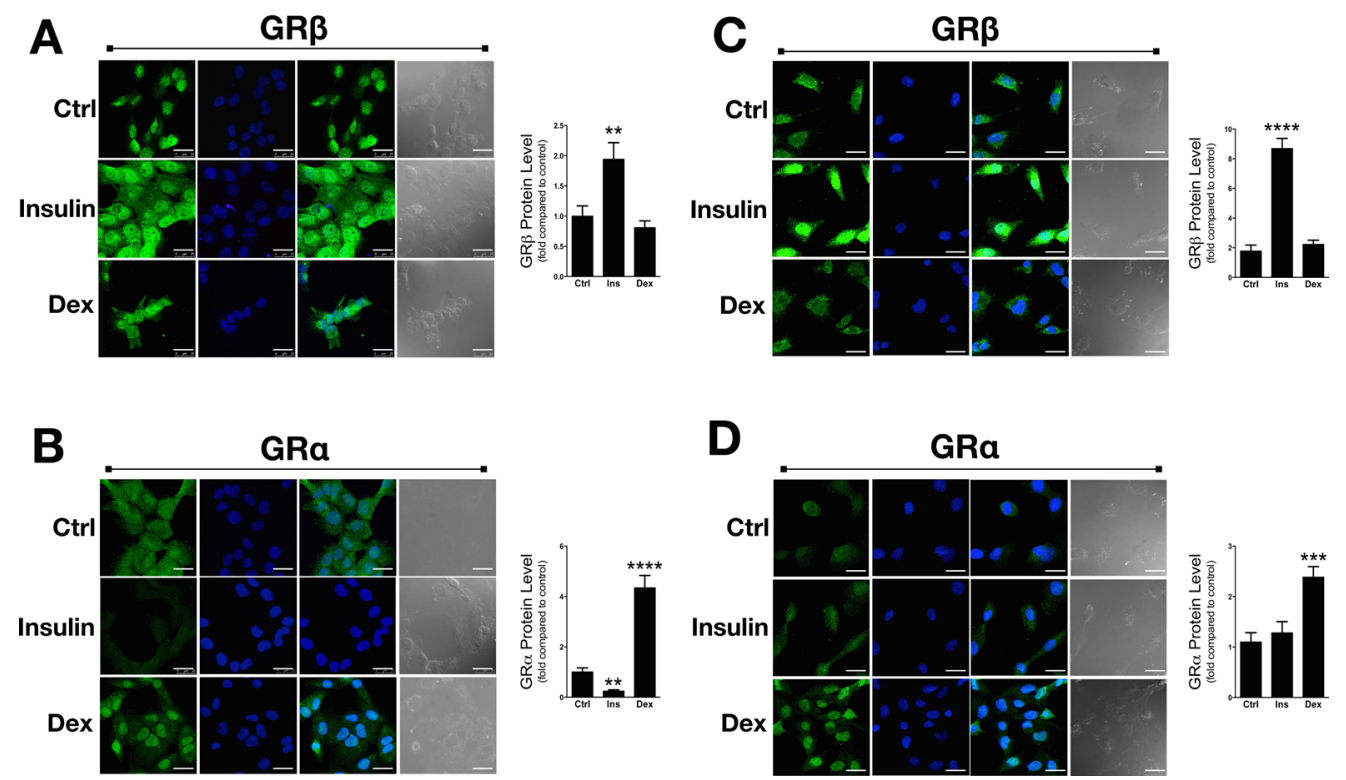

Figure 3: Dexamethasone and insulin treatment in T24 and UMUC-3 cells. GR $\beta$ and GR $\alpha$ expression and location was measured using immunoflourescence with control (vehicle treatment), dexamethasone, or insulin treatments (A-D). Cells were seeded onto coverslips in media containing 10\% dialyzed FBS for 24 hours before treating. Cells were treated with $100 \mathrm{nM}$ insulin, $100 \mathrm{nM}$ dexamethasone, or vehicle for 30 minutes. Secondary antibodies (labeling of human GR $\alpha$ or GR $\beta$ ) are shown in green, DAPI (nuclei labeling) are shown in blue, a merge of the green and blue images are shown in panel 3 to represent localization, and a bright field image is shown in gray (scale bar $=25 \mu \mathrm{m})$. Data are represented as fold change compared to control. $*^{*} p<0.01 ; * * * p<0.001 ; * * * * p<0.0001$ (versus control) ( \pm S.E.; $n=3$ ).

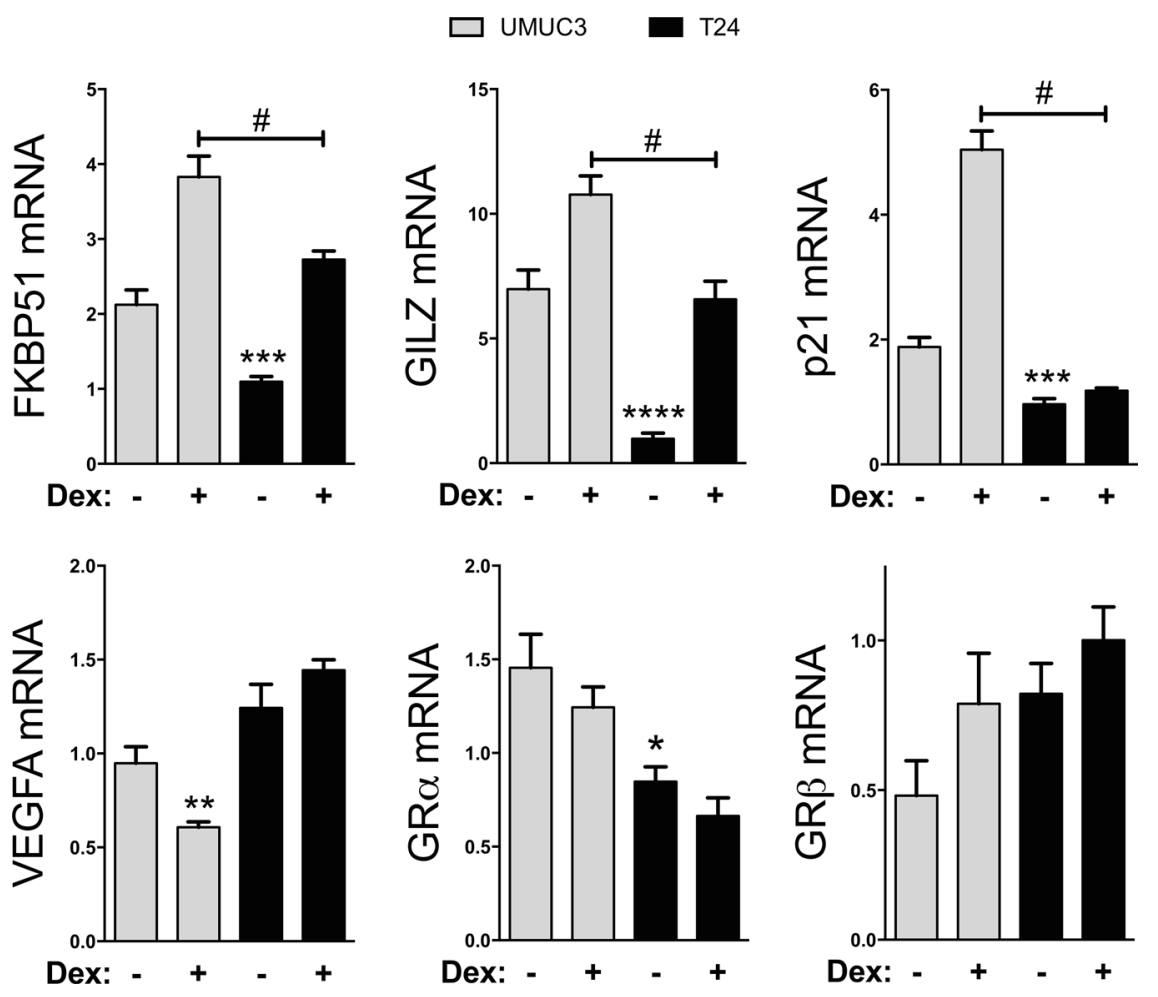

Figure 4: GR $\alpha$ controlled gene expression in T24 and UMUC-3 human bladder cancer cells. GR $\alpha$ controlled gene response was measured by Real-time PCR for FKBP51, GILZ, p21, VEGFA, GR $\alpha$, and GR $\beta$. Cells were seeded in media containing $10 \%$ Dialyzed FBS for 24 hours before treatment. Cells were then treated with $100 \mathrm{nM}$ dexamethasone or vehicle for 2 hours before mRNA was harvested. ${ }^{*} p<0.05 ; * *<0.01 ; * * * p 0.001 ; * * * *<0.0001$ (versus UMUC3 control); $\# p<0.05$ (versus UMUC3 Dex) $( \pm$ S.E.; $n=3$ ). 


\section{GRß expression is controlled by miRNAs}

To assay miRNA control of GR $\beta$ expression, we used the in-silico prediction software Targetscan (version 6.2) to find miRNAs that may bind to the 3'-UTR of human GR $\beta$ (Supplementary Figure 1) [37-39]. Three miRNAs were predicted to bind the 3'UTR of human GR $\beta$ (miR33a, miR181-a/b/c/d, and miR144). To determine which of the predicted miRNAs may regulate human GR $\beta$ expression, we used the pMirTarget vector with the 3' UTR of human GR $\beta$ (pMirTarget 3' UTR hGR $\beta$ ) inserted after the luciferase reporter gene, which is under the control of the IRES promoter (Figure 5A). Next, we mutated the predicted binding sites to all adenines (Supplementary Figure 2) to determine the potential of the miRNA on human GR $\beta$ expression. We transfected the UMUC- 3 and T2 4 cells with the pMirTarget $3^{\prime}$ UTR hGR $\beta$ mutants and measured luciferase activity (Figure 5B). Mutational analysis of the miR144 binding site resulted in a decrease of $77 \%$ (UMUC-3) and $81 \%$ (T24) in the
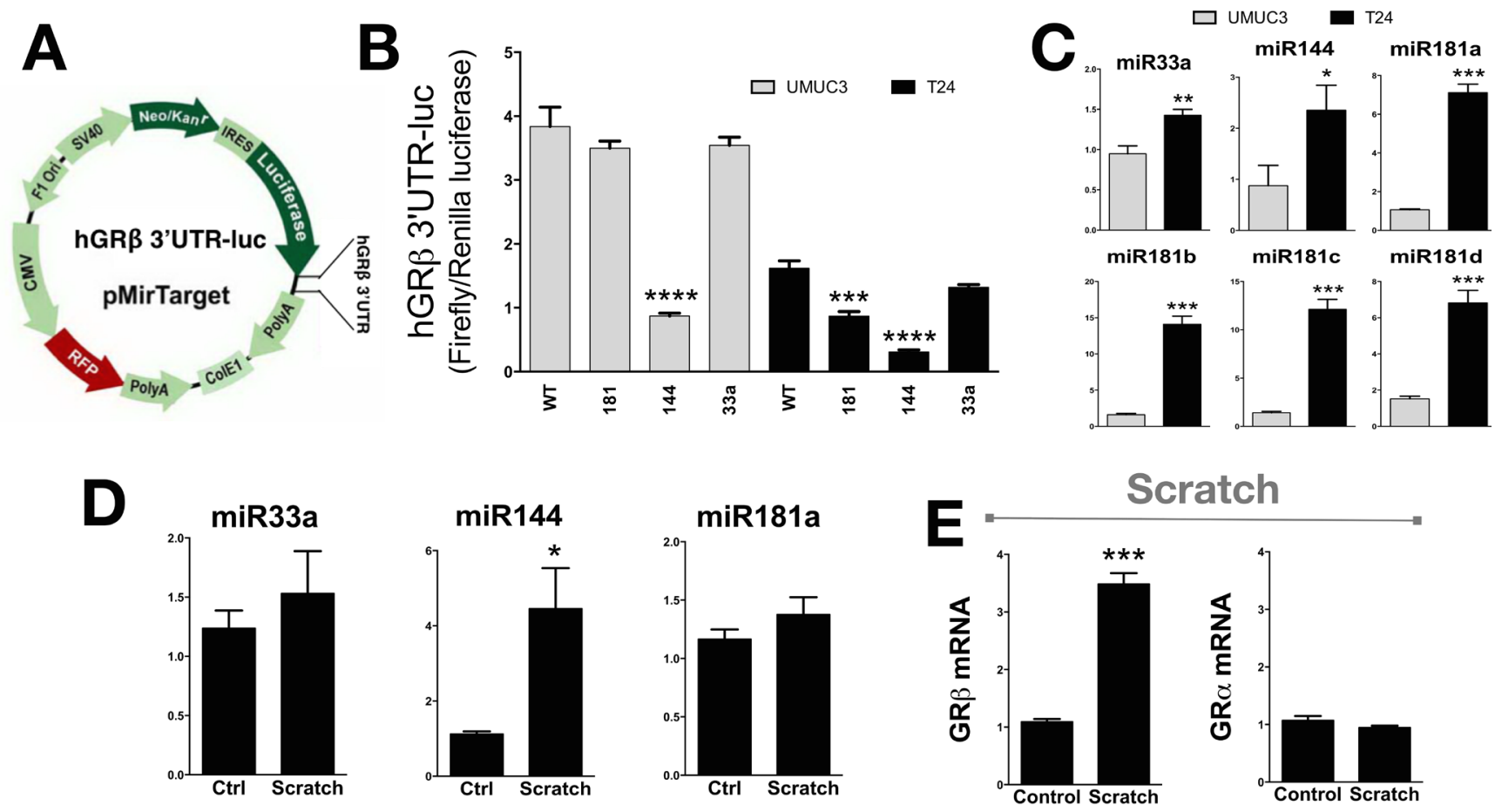

Scratch
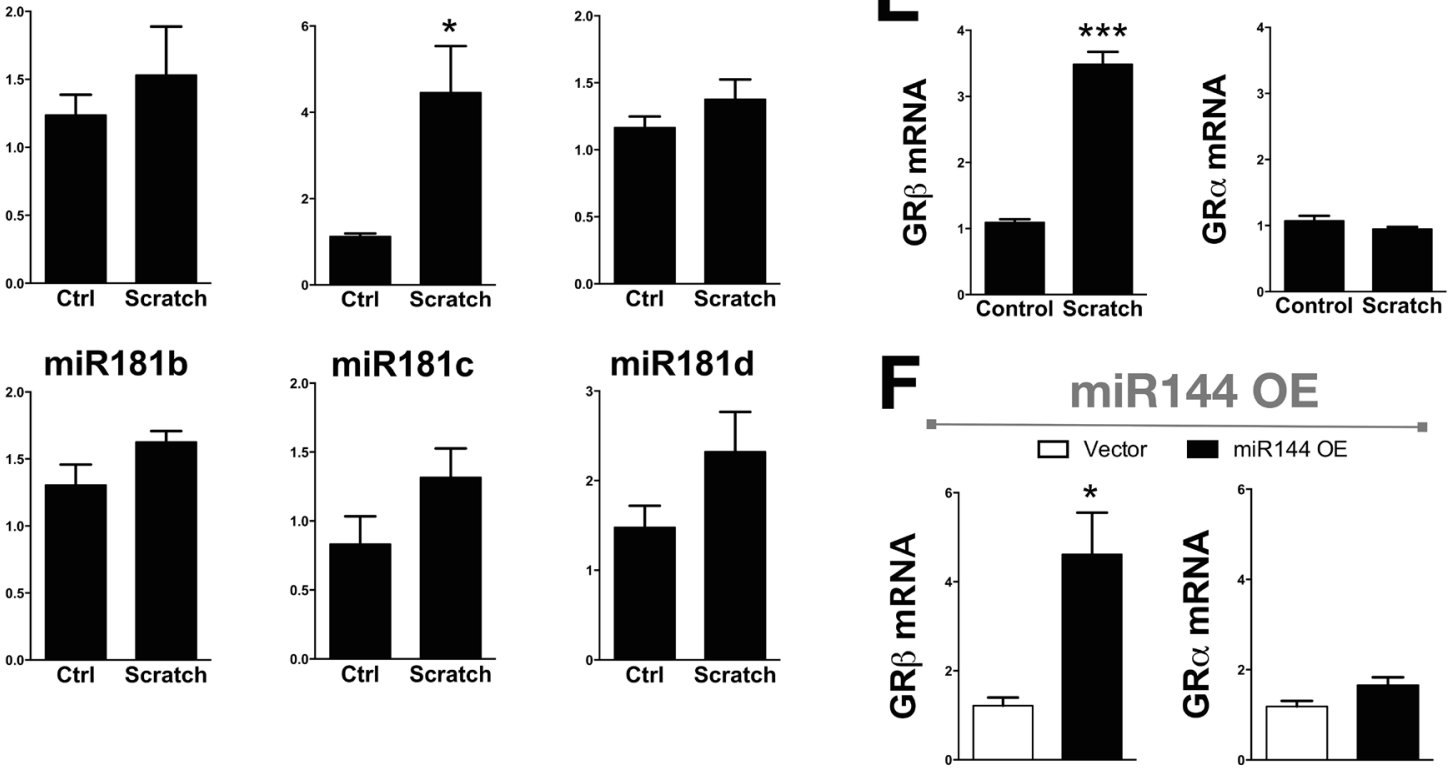

Figure 5: The human $3^{\prime}$ UTR of GR $\beta$ is regulated by miR144. The pMirTarget vector containing the $3^{\prime} U T R$ of human GR $\beta$ was cloned into a luciferase reporter gene (3'UTR GR $\beta$-Luc) (A). The T24 and UMUC-3 bladder cancer cells were transfected with the $3^{\prime}$ UTR GR $\beta$-Luc expression construct with mutation in the miRNA binding site for miR181, miR144, or miR33a and was measured by a luciferase assay, and normalized to renilla $(\mathbf{B}) .{ }^{* * *} p<0.001 ; * * * * p<0.0001$ (versus WT) $( \pm$ S.E.; $n=6$ ). The miRNA expression in the UMUC3 and T24 cells was measured using Real-Time PCR $(\mathbf{C}) .{ }^{*} p<0.05 ; * * p<0.01$ (versus UMUC3) ( \pm S.E.; $n=3$ ). Total RNA was harvested at the time of wounding and 3 hours after from the T24 cells in media containing 10\% dialyzed FBS to determine the expression during migration assay for miRNA expression (D). ${ }^{*} p<0.05$ (versus T0) ( \pm S.E.; $n=3$ ), and for mRNA expression of GR $\beta$ and GR $\alpha$ expression (E). $* * * p<0.001$ (versus T0) $( \pm$ S.E.; $n=3$ ). A plasmid containing the human miR144 in the pCMV-MIR vector was transfected in the T24 cells to show how miR144 overexpression affected the expression of GR $\beta$ and GR $\alpha$ as measured by Real-time PCR (F). * $p<0.05$ (versus T24 Vector) ( \pm S.E.; $n=3)$. 
reporter expression, indicating that miR144 may enhance human GR $\beta$ expression. Interestingly, mutation of the miR181 site also decreased of luciferase in pMirTarget 3' UTR hGR $\beta$, but this was not observed in the UMUC3. Total RNA was extracted from the UMUC-3 and T24 cells to measure the miRNA expression that may target the 3' UTR of human GR $\beta$ (Figure 5C). Interestingly, miR33a, miR144, miR181a, miR181b, miR181c, and miR181d were all increased in the T24 cells. Next, we wanted to determine if miR33a, miR144, miR181a, miR181b, miR181c, or miR181d changed during a scratch assay and if this affected the human GR $\beta$ or GR $\alpha$ expression. A scratch (wounding) assay of the T24 cell line showed that miR144 (4 fold) and GR $\beta$ (3.2 fold) were both increased (Figure 5D and 5E). The miR33a, miR181a, miR181b, miR181c, and miR181d were unchanged during the scratch (wounding) assay. Interestingly, GR $\alpha$ mRNA expression was also unchanged with the scratch (wounding) assay.
To show that miR144 specifically regulates human GR $\beta$, we overexpressed a plasmid containing the precursor of human miR144 in pCMV-MIR or empty vector. The miR144 containing pCMV-MIR vector resulted in a 184-fold increase in miR144 expression compared to the empty vector $(p=0.002)$. The overexpression of miR144 resulted in a significant $(p<0.05)$ increase in human GR $\beta$ expression (3.8 fold), while not changing GR $\alpha$ (Figure 5F).

\section{Dexamethasone control of migration and miRNA expression}

Next, we investigated the effect of Dex on migration and regulation of miRNA expression. Dex treatment was performed 30 minutes before scatch assay (wounding) of the T24 bladder cancer cells. The Dex treatment significantly (ANOVA: $p<0.001$ ) decreased migration, while there was no affect in the UMUC-3 cells (Figure 6A).

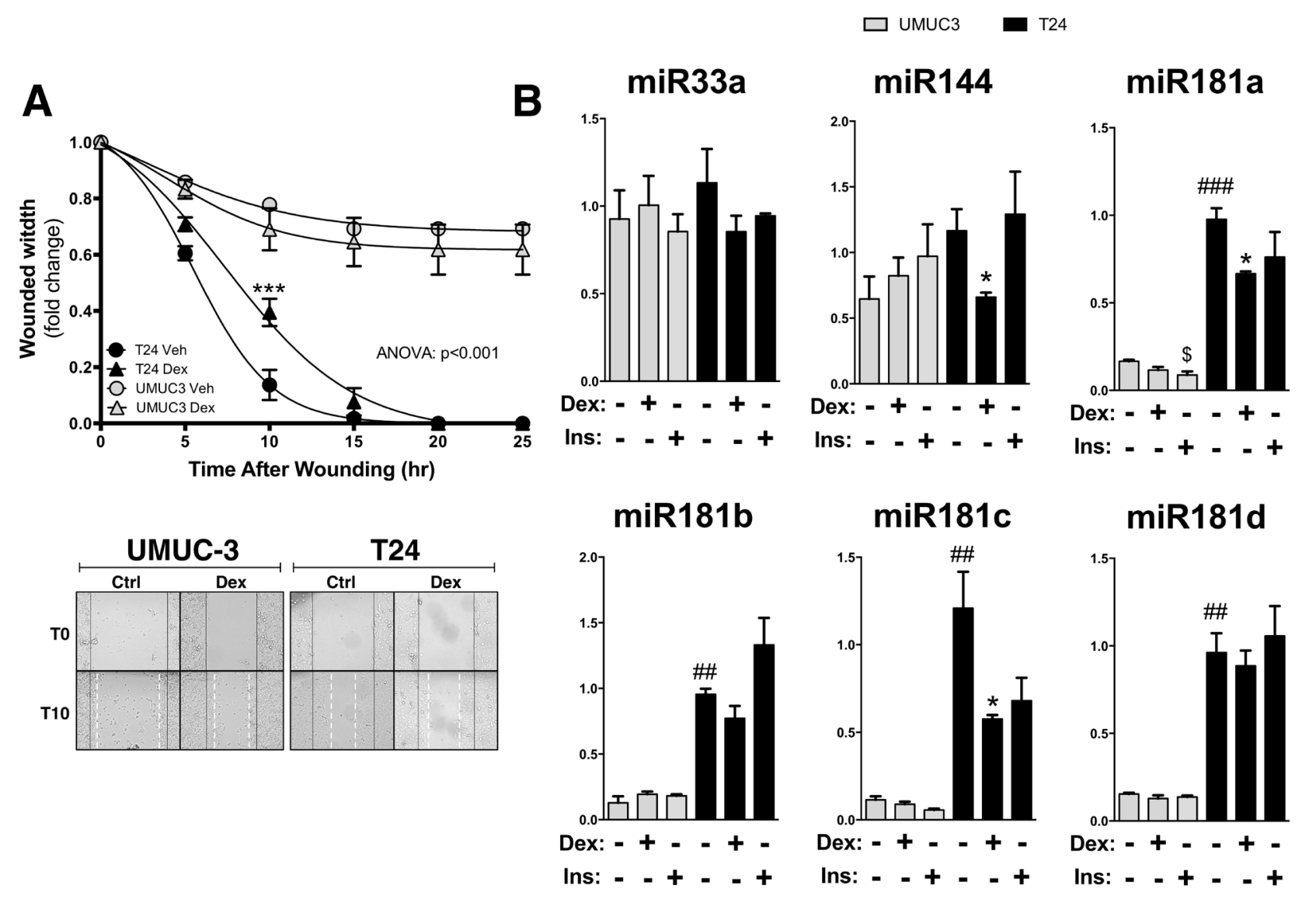

Figure 6: The effect of dexamethasone treatment on cell migration and miRNA expression in UMUC-3 and T24 bladder cancer cells. Migration was measured in the UMUC-3 and T24 cells that were treated with either vehicle or 100 nM dexamethasone for 30 minutes prior to wounding, and is presented as the fold-change in the wound width remaining (A). Images of the migration assay at 0 and 10 hours post wounding are shown, with wound edges marked at T0 (black solid line) and T15 (white dashed line). ANOVA $p<0.001$; Bonferoni comparisons $* * * p<0.0001$ (versus Vehicle) $( \pm$ S.E.; $n=6$ ). Total RNA was extracted from the UMUC3 and T24 cells after treating with either vehicle, $100 \mathrm{nM}$ dexamethasone, or $100 \mathrm{nM}$ Insulin in dialyzed media for 2 hours before harvesting, and miRNA expression was measured by Real-time PCR (B). * $p<0.05$; (Dex versus Veh); $\$ p<0.05$; (Ins versus Veh); \#\#p $<0.01$; \#\#p $<0.001$; (T24 versus UMUC3) $( \pm$ S.E.; $n=6)$. 
Dex treatment decreased expression of miR144, miR181a, and miR181c in the T24 cells, but not in the UMUC-3 cells (Figure 6B). Insulin did not significantly change expression of miR33a, miR144, miR181a, miR181b, miR181c, or miR181d in the T24 cells. However, insulin did suppress miR181a expression in the UMUC-3 cells.

\section{Drug targeting the miR144 enhancement of GRß}

To inhibit the binding of miR144 to the 3'UTR of GR $\beta$, we developed a peptide nucleic acid (PNA) conjugated with a cell-penetrating peptide (CPP) (Sweet-P) targeting the site (Figure 7A). A dose dependence response curve indicated that Sweet-P significantly $(p<0.05)$ decreased GR $\beta$ mRNA expression in the T24 human bladder cancer at $1.0 \mathrm{nM}, 10 \mathrm{nM}, 50 \mathrm{nM}$, and $100 \mathrm{nM}$ (Figure 7B). To confirm our endogenous gene finding, we transfected the T24 bladder cancer cells with the pMirTarget $3^{\prime}$ UTR hGR $\beta$ construct and treated with Sweet-P for 48 hours (Figure 7C). The luciferase expression of the pMirTarget $3^{\prime}$ UTR hGR $\beta$ construct was significantly $(p<0.001)$ reduced at $0.1 \mathrm{nM}, 1.0 \mathrm{nM}$, and $10 \mathrm{nM}$. Sweet-P (10 $\mathrm{nM})$ reduced GR $\beta$ protein expression, but had no effect on GR $\alpha$ (Figure 7D). Furthermore, Sweet-P significantly increased GR $\alpha$ activity with dexamethasone treatment by enhancing expression of FKBP51 $(p<0.05)$ and decreasing a known GR $\alpha$ regulated gene, tumor necrosis factor $\alpha$ (TNF $\alpha$ ) (Figure 7E). To show that Sweet-P specifically targets miR144-binding site in the 3'UTR of hGR $\beta$, we measured protein expression by immunohistochemistry of two known miR144 targets that have been shown to be suppressed, PTEN [35] and the mammalian target of rapamycin (mTOR) [40]. The results show that mTOR expression
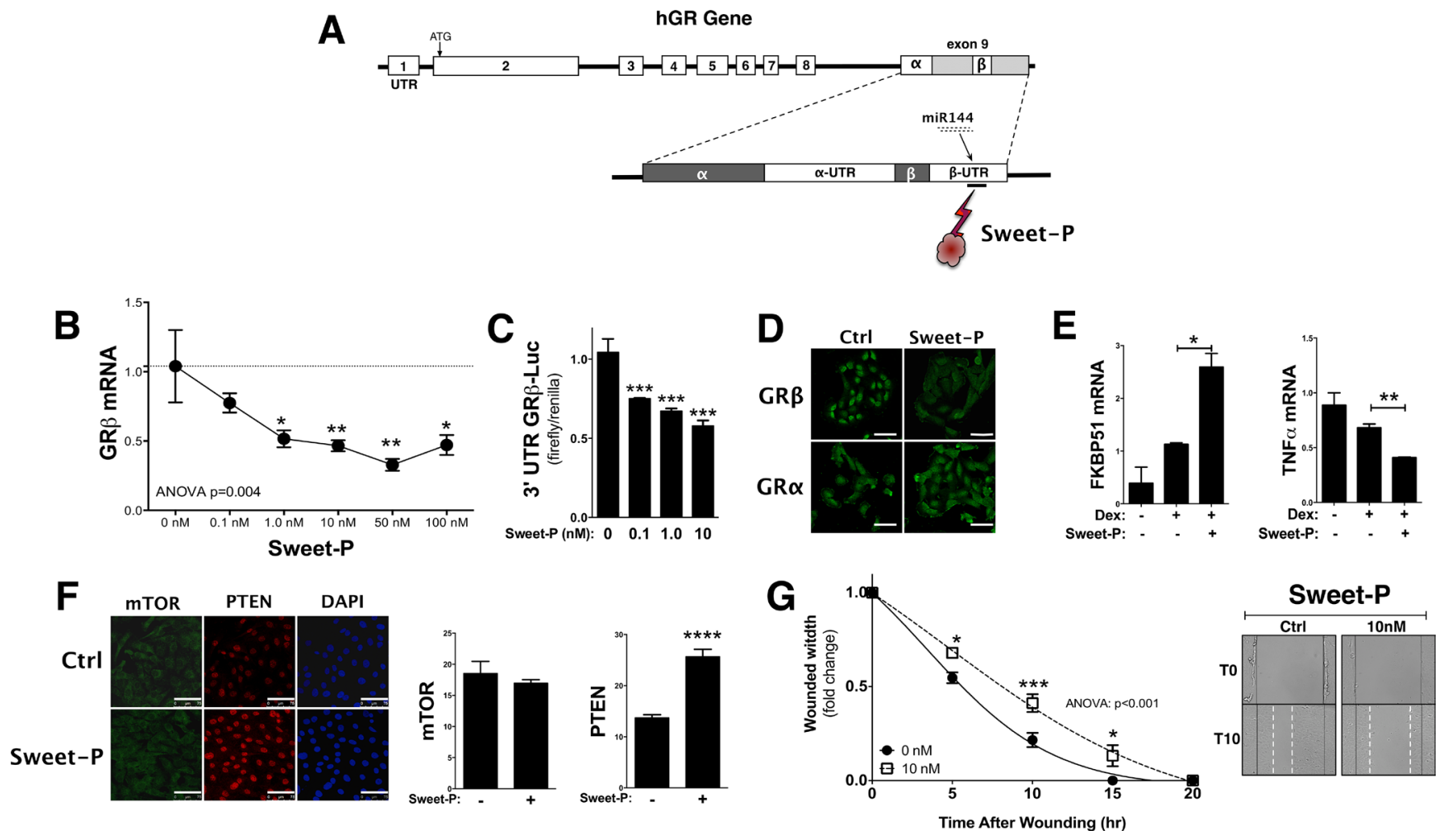

Figure 7: Blocking the miR144 binding site in the 3'UTR of human GR $\beta$ by Sweet-P inhibits expression and cell migration. A peptide nucleic acid (PNA) conjugated to a cell penetrating peptide (CPP) (Sweet-P) was designed to bind to the miR144 binding site in the 3'UTR of human GR $\beta$ mRNA (A). GR $\beta$ expression in T24 cells was measured at increasing doses of Sweet-P $(0,0.1$, $1.0,10,50$, and $100 \mathrm{nM}$ ) for 48 hours after and human GR $\beta$ mRNA was measured by Real-time PCR (B). ANOVA $p<0.01$; Dunnett's comparisons $* p<0.05 ; * *<0.01$ (versus $0 \mathrm{nM})( \pm$ S.E.; $n=6)$. The 3'UTR GR $\beta$-Luc was used to determine the dose dependence of Sweet-P $(0,0.1,1.0$, and $10 \mathrm{nM})$ by luciferase $(\mathbf{C}) . * * * p<0.001$ (versus $0 \mathrm{nM})( \pm$ S.E.; $n=4)$. Immunostaing of human GR $\beta$ and GR $\alpha$ with $10 \mathrm{nM}$ Sweet-P treatment for 48 hours in T24 bladder cancer cells (D). Sweet-P treatment for 48 hours and then 2 hours of dexamethasone in T24 cells and Real-time PCR analysis of FKBP51 and tumor necrosis factor $\alpha(\mathrm{TNF} \alpha)(\mathbf{E}) .{ }^{*} p<0.05 ; * * p 0.01$ (versus no dex or Sweet-P control) ( \pm S.E.; $n=3$ ). Immunostaing of mTOR and PTEN with 10nM Sweet-P treatment for 48 hours in T24 bladder cancer cells (D) (scale bar $=75 \mu \mathrm{m}$ ). Migration was measured in the T24 after being treated with $10 \mathrm{nM}$ Sweet-P for 48 hours prior to wounding, and is presented as the fold-change for the wound width remaining $(\mathbf{G})$. Images of the migration assay at 0 and 10 hours post wounding are shown, with wound edges marked at T0 (black solid line) and T15 (white dashed line). ANOVA $p<0.001$; Dunnet comparisons $* p<0.05 ; * * p<0.01$; $* * * p<0.0001$ (versus $0 \mathrm{nM})( \pm$ S.E.; $n=6)$. 
is unaffected by Sweet-P (10 nM), and PTEN expression was significantly $(p<0.0001)$ increased with treatment. To determine if Sweet-P could inhibit migration, we treated the T24 bladder cancer cells with $10 \mathrm{nM}$ Sweet-P during a scratch (wounding) assay. The results show that Sweet-P significantly (ANOVA: $p<0.001$ ) inhibited migration of the T24 bladder cancer cells during migration (Figure 7D).

\section{DISCUSSION}

This is the first study to show that GR $\beta$ is enhanced during the migration of human bladder cancer cells. Suppression of GR $\beta$ by lentiviral shRNA decreased the migration of T24 cells. Yin et al. showed that GR $\beta$ increases the migration of astrocytes and brain cancer cells (glioblastoma) [22]. Several other studies have also demonstrated that GR $\beta$ is elevated in cancers and inflammatory diseases, which leads to increased growth [20, 41-46]. GCs have been shown to inhibit migration and proliferation of cancer cells in medulloblastoma [47], osteosarcomas [48, 49], A549 human lung cancer cells [50], as well as other lung cancer cells: squamous cell carcinoma lines (EPLC-32M1 and NCI-H157), large-cell carcinoma cell line (LCLC-97TM1) and a cell line from mesothelioma (MSTO-211H) [51]. Increasing GR $\beta$ may provide a state of $\mathrm{GC}$ resistance that reduces their ability to inhibit growth and migration. Bombesin has been shown to induce resistance to GCs by induction of GR $\beta$ in human prostate cancer cells [43]. We showed in this study that the T24 human bladder cancer cells had a reduced response to GCs compared to the UMUC-3, which may be due to elevated GR $\beta$. The migratory potential of T24 cells, but not the UMUC3 cells, was inhibited by dexamethasone. Dexamethasone has been previously shown to inhibit the invasion of bladder cancer cells, including the UMUC-3 [18]. In this study, we show that dexamethasone treatment inhibited miR144, which we have shown is a positive regulator of GR $\beta$ and is increased during migration. The inhibition of miR144 may be a potential mechanism that migration was reduced by dexamethasone in the T24 cells.

As shown by the mutation in the 3'UTR of human GR $\beta$ reporter, and plasmid overexpression, miR144 is a positive regulator of human GR $\beta$ expression and not GR $\alpha$. Iwaya et al. showed that miR144 downregulated mTOR, a regulator of cellular growth and metabolism, and the loss of miR144 leads to the progression of colorectal cancer [40]. Zhang et al. showed that miR144 downregulated PTEN expression [35], a tumor suppressor gene that regulates many cellular functions including cell proliferation. Guo et al. showed that miR144 inhibits bladder cancer proliferation by targeting the enhancer the zeste homolog 2 (EZH2), a downstream regulator of the Wnt/ $\beta$-catenin pathway that mediates growth [34]. However, the effects of miR144 on migration were not tested. There are a plethora of targets for miRNAs, and the specific blockade of miR144 binding to the $3{ }^{\prime} \mathrm{UTR}$ of GR $\beta$ by Sweet-P resulted in decreased GR $\beta$ mRNA expression and 3'UTR GR $\beta$-luc reporter assay. The effect of Sweet-P was specific for the 3'UTR of human GR $\beta$, as mTOR and PTEN, which are known to be suppressed by miR144, were not lower but PTEN was significantly higher. We have recently shown that GR $\beta$ binds to the PTEN promoter to inhibit expression [8], and therefore the suppression of GR $\beta$ by Sweet-P treatment caused derepression of PTEN. Sweet-P did suppress GR $\beta$ protein expression, but did not change GR $\alpha$. However, the GR $\alpha$ activity was increased with Sweet-P treatment. Moreover, the downregulation of GR $\beta$ by Sweet-P inhibited migration of bladder cancer cells, indicating that it may serve as a potential therapy for bladder cancer. The inhibitory effect of dexamethasone on the migration of the T24 cells supports that GR $\alpha$ is a suppressor of bladder cancer, which is also shown by Sweet-P enhancing GR $\alpha$ activity and suppressing migration of the bladder cancer cells. Dexamethasone inhibition of VEGF-A supports that GCs may inhibit bladder cancer, VEGF-A levels were found to be greater in higher-grade urothelial tumors [52]. Dexamethasone decreased miR144 and migration of the T24 cells, which indicates that suppression of miR144 levels may also reduce GR $\beta$ expression. However, twohour dexamethasone treatment in hormone-free serum did not affect GR $\beta$ mRNA, or 30-minute treatment did not change the protein. Glucocorticoids may alter GR $\beta$ expression with longer treatment. We showed in mouse fibroblast that GR $\beta$ increased with dexamethasone treatment [7], but no change was observed in mouse C2C12 myoblast [53]. During migration, dexamethasone suppression of miR144 may have a larger impact on GR $\beta$ expression.

The effect of insulin on enhancing GR $\beta$ expression and inhibiting GR $\alpha$ suggests that it may increase the risk of bladder cancer. However, insulin did not increase miR144 expression with an acute two-hour treatment, which suggests that insulin may enhance GR $\beta$ levels by a different mechanism. The effect of insulin on cancer cell migration rate has not been studied, but the insulinlike growth factor receptor I (IGFR-I) has been shown to promote invasion of bladder cancer cells through an Akt and mitogen activated protein kinase (MAPK) dependent mechanism [54]. There has been no correlation found for bladder cancer in insulin-resistant type II diabetics [55], which suggests that insulin may not have a role. However, IGF-I may signal to GR $\beta$ to increase bladder cancer invasion, but the effect of IGF-I on GR $\beta$ expression has not been investigated. Most likely the increase of miR144 during T24 migration and its enhancement of GR $\beta$ expression are mediated in a non-insulin dependent manner. Two drugs for the treatment of type II diabetes, rosiglitazone and pioglitazone, have been shown to induce bladder cancer $[56,57]$, but their effect on miR144 or GR $\beta$ expression is unknown. Recent studies have revealed that there is a 3:1 incidence in men compared to women for 
bladder cancer, which may be mediated by the androgen receptor (AR) [4]. Presumably, there may be an interaction between AR and GR $\beta$ in prostate cancer. Ligr et al. showed that suppression of GR $\beta$ in LNCaP, RC165, and DU145 human prostate cancer cells inhibited growth [58]. However, the signaling involvement of GR $\beta$ and AR in bladder cancer has not been investigated.

In conclusion, GR $\beta$ mediates bladder cancer migration and may serve as a target for therapy. The 3' UTR of GR $\beta$ is enhanced by miR144 during human bladder cancer migration. Blocking the interaction of miR144 with the 3' UTR of GR $\beta$ by Sweet-P slowed bladder cancer migration. The antagonism of human GR $\beta$ by Sweet-P, drug interaction, or gene targeting may serve as a potential treatment for bladder cancer.

\section{MATERIALS AND METHODS}

\section{Cell lines and culture}

The human uroepithelial carcinoma cell lines UMUC-3 and T24 (ATCC) were routinely cultured and maintained in Minimum Essential Medium (MEM) containing $10 \%$ fetal bovine serum (FBS) with $1 \%$ antibiotic-antimycotic. Cells were maintained at $37^{\circ} \mathrm{C}$ and $5 \% \mathrm{CO}^{2}$. Media was changed to MEM containing $10 \%$ dialyzed-FBS with $1 \%$ antibiotic-antimycotic 24 hours before hormone treatments.

\section{RNA extraction for mRNA quantification and real-time PCR analysis}

Total RNA was extracted from cell cultures using the 5-Prime PerfectPure RNA Cell Kit (Fisher Scientific Company, LLC). Total RNA was read on a Nano Drop 2000 spectrophotometer (Thermo Fisher Scientific, Wilmington, DE) and cDNA was synthesized using High Capacity cDNA Reverse Transcription Kit (Applied Biosystems). PCR amplification of the cDNA was performed by quantitative real-time PCR using TrueAmp SYBR Green qPCR SuperMix (Smart Bioscience). The thermocycling protocol consisted of $10 \mathrm{~min}$ at $95^{\circ} \mathrm{C}$, 40 cycles of $15 \mathrm{sec}$ at $95^{\circ} \mathrm{C}, 30 \mathrm{sec}$ at $60^{\circ} \mathrm{C}$, and $20 \mathrm{sec}$ at $72^{\circ} \mathrm{C}$ and finished with a melting curve ranging from $60-95^{\circ} \mathrm{C}$ to allow distinction of specific products. Normalization was performed in separate reactions with primers to GAPDH.

\section{RNA extraction for miRNA quantification and real-time PCR analysis}

Total RNA was extracted from cell cultures using the miRNeasy Mini Kit (Qiagen). Total RNA was read on a Nano Drop 2000 spectrophotometer (Thermo Fisher Scientific, Wilmington, DE) and cDNA was synthesized using the miScript II RT Kit (Qiagen). PCR amplification of the
cDNA was performed by quantitative real-time PCR using miScript SYBR Green PCR Kit (Qiagen). The thermocycling protocol consisted of $15 \mathrm{~min}$ at $95^{\circ} \mathrm{C}, 40$ cycles of $15 \mathrm{sec}$ at $94^{\circ} \mathrm{C}, 30 \mathrm{sec}$ at $55^{\circ} \mathrm{C}$, and $30 \mathrm{sec}$ at $70^{\circ} \mathrm{C}$ and finished with a melting curve ranging from $60-95^{\circ} \mathrm{C}$ to allow distinction of specific products. The miScript Primer Assay primers were purchased from Qiagen. Normalization was performed in separate reactions with primers to Hs_RNU6-2_11, At U19_1, and Hs_SNORD61_11.

\section{Immunoflourescence and microscopy}

Samples were imaged using a Leica TCS SP5 laser scanning confocal microscope (Leica Microsystems, Bannockburn, IL) equipped with conventional solid state and a Ti-sapphire tunable multiphoton laser (Coherent, Santa Clara, CA). Images were acquired in the XYZ plane in $1 \mu \mathrm{m}$ steps with a $63 \mathrm{X}$ oil objective (NA 1.40). Images were acquired with the LAS AF software in sequential scan mode. Alexa Fluor 488 was excited at $488 \mathrm{~nm}$ with collection at 500-558 nm and DAPI was excited with the multi-photon (MP) laser tuned to $790 \mathrm{~nm}$ with collection at $420-500 \mathrm{~nm}$. Images are 2D projections of the of image stack as labeled. Three images were taken per slide and ImageJ software was used to measure the immunofluorescence of each cell (average 40 cells) in the images.

\section{Migration assay}

Cells were seeded on a 6-well plate and grown for 24 hours until a monolayer of $90 \%$ confluent cells were obtained. A scratch wound in the cell monolayer was introduced using a sterile pipette tip. Images were taken at the time of wounding, and every 5 hours thereafter. Migration was measured as the fold change of the width of the wound remaining. To determine miRNA and mRNA expression during the scratch (wounding assay), we collected total RNA using the miRNeasy Mini Kit (Qiagen) (described above) at 0 and 3 hours after the migration.

\section{Generation of lentiviral constructs}

To establish a T24 cell line that has hGR $\beta$ stably knocked down, the pGFP-C-shLenti plasmid containing either GR $\beta$ shRNA (CCAGAAAGCACATCT CACACATTAATCTG) or scrambled shRNA (Origene) was packaged into a lentiviral construct using the Lenti-vpak Packaging Kit (Origene) by transfection in 293-GP2 cells. The supernatants were harvested and the cell debris was removed by filtration through $0.45 \mu \mathrm{M}$ filter. The supernatant was used to infect T24 cells after addition of polybrene (10 ug/ml, Sigma Chemical Co., St. Louis, MO) to establish cell lines with stable expression of hGR $\beta$ shRNA (T24 GR $\beta$ KD) or expressing scrambled shRNA (T24 Scramble). After $72 \mathrm{~h}$ the cells were initially selected using Puromycin $(10 \mu \mathrm{g} / \mathrm{mL})$. Cells were then secondarily selected by sorting 
through flow cytometry for GFP by the Flow Cytometry Core Facility at the University of Toledo Health Science Campus.

\section{Transient transfection}

For transient transfection cells were plated on a 6-well or 12-well dish in MEM containing 10\% FBS. Cells were washed with OPTI-MEM and transfected using GeneFect (Alkali Scientific, Inc.), according to the manufacturer's protocol. OPTI-MEM was removed after $12 \mathrm{~h}$ and MEM containing 10\% FBS was added.

\section{Promoter reporter assays}

The expression vector pMirTarget containing the 3'UTR of hGR $\beta$ (hGR $\beta$ 3'UTR-luc) was purchased from (Origene). The binding sites were mutated using the Quik Change Lightning Multi Site-Directed Mutagenesis Kits (Agilent Technologies). Successful mutations were confirmed through sequencing by Operon MWG. Cells were seeded onto a 12-well plate and grown overnight. Transient transfection was performed as described above. To determine the effect of Sweet-P on the T24 bladder cancer cells, we treated $24 \mathrm{~h}$ after transfection for 48 hours post transfection, 3 'UTR GR $\beta$-Luc WT or mutant expression was measured by luciferase, and pRL-CMV Renilla reporter for normalization to transfection efficiency, using the Promega dual luciferase assay system (Promega, Madison, WI).

\section{miRNA overexpression}

The cloning vector pCMV-MIR containing the miR144 sequence was purchased from Origene. Cells were seeded on a 6-well plate, and transient transfection of the plasmid was completed as above. After 48 hourspost transfection, RNA was harvested as described above.

\section{Targeting of the human GR $\beta$ mRNA}

A peptide nucleic acid (PNA) conjugated to a cell penetrating peptide (CPP) targeting the miR144 binding site in the $3^{\prime}$ UTR of the human GR $\beta$ (Sweet-P) was designed using PANAGENE website (http://www.panagene.com). The Sweet-P sequence targeted the miR144 binding site in the 3' UTR of human GR $\beta$ (Supplementary Figure 2). All PNAs were attached to an O Linker and a modified TAT protein (VQRKRQKLMP) for delivery into the cell (CPP). Treatment with Sweet-P was performed for $48 \mathrm{hrs}$ before the cells were analyzed.

\section{Statistical analysis}

Data were analyzed with Prism 5 (GraphPad Software, San Diego, CA) using analysis of variance combined with Tukey's post-test to compare pairs of group means or unpaired $t$ tests. Additionally, two-way ANOVA was utilized in multiple comparisons, and followed by either the Bonferroni or Dunnet post hoc analyses to identify interactions. $p$ values of 0.05 or smaller were considered statistically significant.

\section{ACKNOWLEDGMENTS AND FUNDING}

The authors would like to thank Dr. Kathryn Eisenmann for assistance with the migration assays for these studies. Research reported in this publication was supported by the National Heart, Lung, And Blood Institute of the National Institutes of Health under Award Number K01HL125445 (T.D.H.) and L32MD009154 (T.D.H.). The content is solely the responsibility of the authors and does not necessarily represent the official views of the National Institutes of Health.

\section{CONFLICTS OF INTEREST}

The authors declare no conflicts of interest.

\section{REFERENCES}

1. Society AC. (2015). Cancer Facts \& Figures 2015. (Atlanta, Ga: American Cancer Society).

2. Dietrich K, Schned A, Fortuny J, Heaney J, Marsit C, Kelsey KT, Karagas MR. Glucocorticoid therapy and risk of bladder cancer. Br J Cancer. 2009; 101:1316-1320.

3. Ishiguro H, Kawahara T, Zheng Y, Netto GJ, Miyamoto H. Reduced glucocorticoid receptor expression predicts bladder tumor recurrence and progression. Am J Clin Path. 2014; 142:157-164.

4. McBeth L, Grabnar M, Selman S, Hinds TD, Jr. Involvement of the Androgen and Glucocorticoid Receptors in Bladder Cancer. Int J Endocrinol. 2015; 2015:384860.

5. Chrousos GP, Kino T. Intracellular glucocorticoid signaling: a formerly simple system turns stochastic. Science's STKE. 2005; 2005:pe48.

6. Lewis-Tuffin LJ, Cidlowski JA. The physiology of human glucocorticoid receptor beta (hGRbeta) and glucocorticoid resistance. Ann NY Acad Sci. 2006; 1069:1-9.

7. Hinds TD, Jr., Ramakrishnan S, Cash HA, Stechschulte LA, Heinrich G, Najjar SM, Sanchez ER. Discovery of glucocorticoid receptor-beta in mice with a role in metabolism. Mol Endocrinol. 2010; 24:1715-1727.

8. Stechschulte LA, Wuescher L, Marino JS, Hill JW, Eng C, Hinds TD, Jr. Glucocorticoid Receptor beta Stimulates Akt1 Growth Pathway by Attenuation of PTEN. J Biol Chem. 2014.

9. John K, Marino JS, Sanchez ER, Hinds TD, Jr. The Glucocorticoid Receptor: Cause or Cure for Obesity? Am J Physiol Endocrinol Metab. 2015:ajpendo 0047802015.

10. Tata JR. Signalling through nuclear receptors. Nature Rev Mol Cell Biol. 2002; 3:702-710.

11. Kumar R, Johnson BH, Thompson EB. Overview of the structural basis for transcription regulation by nuclear hormone receptors. Essays in biochemistry. 2004; 40:27-39. 
12. Rogatsky I, Trowbridge JM, Garabedian MJ. Glucocorticoid receptor-mediated cell cycle arrest is achieved through distinct cell-specific transcriptional regulatory mechanisms. Mol Cell Biol. 1997; 17:3181-3193.

13. Yemelyanov A, Czwornog J, Chebotaev D, Karseladze A, Kulevitch E, Yang X, Budunova I. Tumor suppressor activity of glucocorticoid receptor in the prostate. Oncogene. 2007; 26:1885-1896.

14. Ni Z, Tang J, Cai Z, Yang W, Zhang L, Chen Q, Zhang L, Wang X. A new pathway of glucocorticoid action for asthma treatment through the regulation of PTEN expression. Respir Res. 2011; 12:47.

15. Bamberger CM, Bamberger AM, de Castro M, Chrousos GP. Glucocorticoid receptor beta, a potential endogenous inhibitor of glucocorticoid action in humans. J Clin Invest. 1995; 95:2435-2441.

16. Leung DY, Hamid Q, Vottero A, Szefler SJ, Surs W, Minshall E, Chrousos GP, Klemm DJ. Association of glucocorticoid insensitivity with increased expression of glucocorticoid receptor beta. The Journal of experimental medicine. 1997; 186:1567-1574.

17. Oakley RH, Jewell CM, Yudt MR, Bofetiado DM, Cidlowski JA. The dominant negative activity of the human glucocorticoid receptor beta isoform. Specificity and mechanisms of action. J Biol Chem. 1999; 274:27857-27866.

18. Zheng Y, Izumi K, Li Y, Ishiguro H, Miyamoto H. Contrary regulation of bladder cancer cell proliferation and invasion by dexamethasone-mediated glucocorticoid receptor signals. Mol Cancer Ther. 2012; 11:2621-2632.

19. Ishiguro H, Kawahara T, Zheng Y, Kashiwagi E, Li Y, Miyamoto H. Differential regulation of bladder cancer growth by various glucocorticoids: corticosterone and prednisone inhibit cell invasion without promoting cell proliferation or reducing cisplatin cytotoxicity. Cancer Chemother Pharmacol. 2014; 74:249-255.

20. Longui CA, Vottero A, Adamson PC, Cole DE, Kino T, Monte O, Chrousos GP. Low glucocorticoid receptor alpha/ beta ratio in T-cell lymphoblastic leukemia. Hormone and metabolic research. 2000; 32:401-406.

21. Nishimura K, Nonomura N, Satoh E, Harada $Y$, Nakayama M, Tokizane T, Fukui T, Ono Y, Inoue H, Shin M, Tsujimoto Y, Takayama H, Aozasa K, Okuyama A. Potential mechanism for the effects of dexamethasone on growth of androgen-independent prostate cancer. J Natl Cancer Inst. 2001; 93:1739-1746.

22. Yin Y, Zhang X, Li Z, Deng L, Jiao G, Zhang B, Xie P, Mu H, Qiao W, Zou J. Glucocorticoid receptor beta regulates injurymediated astrocyte activation and contributes to glioma pathogenesis via modulation of beta-catenin/TCF transcriptional activity. Neurobiol Dis. 2013; 59:165-176.

23. Ledderose C, Mohnle P, Limbeck E, Schutz S, Weis F, Rink J, Briegel J, Kreth S. Corticosteroid resistance in sepsis is influenced by microRNA-124 - induced downregulation of glucocorticoid receptor-alpha. Crit Care Med. 2012; 40:2745-2753.
24. Schaaf MJ, Cidlowski JA. AUUUA motifs in the $3^{\prime}$ UTR of human glucocorticoid receptor alpha and beta mRNA destabilize mRNA and decrease receptor protein expression. Steroids. 2002; 67:627-636.

25. Di Leva G, Garofalo M, Croce CM. MicroRNAs in cancer. Annual review of pathology. 2014; 9:287-314.

26. $\mathrm{Hu} \mathrm{Z}$. Insight into microRNA regulation by analyzing the characteristics of their targets in humans. BMC genomics. 2009; 10:594.

27. Wang W, Peng B, Wang D, Ma X, Jiang D, Zhao J, Yu L. Human tumor microRNA signatures derived from largescale oligonucleotide microarray datasets. Int J Cancer. 2011; 129:1624-1634.

28. Wang G, Chan ES, Kwan BC, Li PK, Yip SK, Szeto CC, $\mathrm{Ng}$ CF. Expression of microRNAs in the urine of patients with bladder cancer. Clinical genitourinary cancer. 2012; 10:106-113.

29. Dyrskjot L, Ostenfeld MS, Bramsen JB, Silahtaroglu AN, Lamy P, Ramanathan R, Fristrup N, Jensen JL, Andersen CL, Zieger K, Kauppinen S, Ulhoi BP, Kjems J, et al. Genomic profiling of microRNAs in bladder cancer: miR-129 is associated with poor outcome and promotes cell death in vitro. Cancer Res. 2009; 69:4851-4860.

30. Miah S, Dudziec E, Drayton RM, Zlotta AR, Morgan SL, Rosario DJ, Hamdy FC, Catto JW. An evaluation of urinary microRNA reveals a high sensitivity for bladder cancer. Br J Cancer. 2012; 107:123-128.

31. Avgeris M, Mavridis K, Tokas T, Stravodimos K, Fragoulis EG, Scorilas A. Uncovering the clinical utility of miR-143, miR-145 and miR-224 for predicting the survival of bladder cancer patients following treatment. Carcinogenesis. 2015; 36:528-537.

32. Huang L, Luo J, Cai Q, Pan Q, Zeng H, Guo Z, Dong W, Huang J, Lin T. MicroRNA-125b suppresses the development of bladder cancer by targeting E2F3. Int $\mathrm{J}$ Cancer. 2011; 128:1758-1769.

33. Chiyomaru T, Enokida H, Tatarano S, Kawahara K, Uchida Y, Nishiyama K, Fujimura L, Kikkawa N, Seki N, Nakagawa M. miR-145 and miR-133a function as tumour suppressors and directly regulate FSCN1 expression in bladder cancer. Br J Cancer. 2010; 102:883-891.

34. Guo Y, Ying L, Tian Y, Yang P, Zhu Y, Wang Z, Qiu F, Lin J. miR-144 downregulation increases bladder cancer cell proliferation by targeting EZH2 and regulating Wnt signaling. The FEBS journal. 2013; 280:4531-4538.

35. Zhang LY, Ho-Fun Lee V, Wong AM, Kwong DL, Zhu YH, Dong SS, Kong KL, Chen J, Tsao SW, Guan XY, Fu L. MicroRNA-144 promotes cell proliferation, migration and invasion in nasopharyngeal carcinoma through repression of PTEN. Carcinogenesis. 2013; 34:454-463.

36. Stechschulte LA, Wuescher L, Marino JS, Hill JW, Eng C, Hinds TD, Jr. Glucocorticoid receptor beta stimulates Akt1 growth pathway by attenuation of PTEN. J Biol Chem. 2014; 289:17885-17894. 
37. Lewis BP, Burge CB, Bartel DP. Conserved seed pairing, often flanked by adenosines, indicates that thousands of human genes are microRNA targets. Cell. 2005; 120:15-20.

38. Garcia DM, Baek D, Shin C, Bell GW, Grimson A, Bartel DP. Weak seed-pairing stability and high target-site abundance decrease the proficiency of lsy-6 and other microRNAs. Nat Struct Mol Biol. 2011; 18:1139-1146.

39. Friedman RC, Farh KK, Burge CB, Bartel DP. Most mammalian mRNAs are conserved targets of microRNAs. Genome Res. 2009; 19:92-105.

40. Iwaya T, Yokobori T, Nishida N, Kogo R, Sudo T, Tanaka F, Shibata K, Sawada G, Takahashi Y, Ishibashi M, Wakabayashi G, Mori M, Mimori K. Downregulation of miR-144 is associated with colorectal cancer progression via activation of mTOR signaling pathway. Carcinogenesis. 2012; 33:2391-2397.

41. Webster JC, Oakley RH, Jewell CM, Cidlowski JA. Proinflammatory cytokines regulate human glucocorticoid receptor gene expression and lead to the accumulation of the dominant negative beta isoform: a mechanism for the generation of glucocorticoid resistance. Proc Natl Acad Sci U S A. 2001; 98:6865-6870.

42. Psarra AM, Solakidi S, Trougakos IP, Margaritis LH, Spyrou G, Sekeris CE. Glucocorticoid receptor isoforms in human hepatocarcinoma HepG2 and SaOS-2 osteosarcoma cells: presence of glucocorticoid receptor alpha in mitochondria and of glucocorticoid receptor beta in nucleoli. Int J Biochem Cell Biol. 2005; 37:2544-2558.

43. Zhu J, Gong JY, Goodman OB, Jr., Cartegni L, Nanus DM, Shen R. Bombesin attenuates pre-mRNA splicing of glucocorticoid receptor by regulating the expression of serine-arginine protein $\mathrm{p} 30 \mathrm{c}(\mathrm{SRp} 30 \mathrm{c})$ in prostate cancer cells. Biochim Biophys Acta. 2007; 1773:1087-1094.

44. Kelly A, Bowen H, Jee YK, Mahfiche N, Soh C, Lee T, Hawrylowicz C, Lavender P. The glucocorticoid receptor beta isoform can mediate transcriptional repression by recruiting histone deacetylases. J Allergy Clin Immunol. 2008; 121:203-208 e201.

45. Varricchio L, Masselli E, Alfani E, Battistini A, Migliaccio G, Vannucchi AM, Zhang W, Rondelli D, Godbold J, Ghinassi B, Whitsett C, Hoffman R, Migliaccio AR. The dominant negative beta isoform of the glucocorticoid receptor is uniquely expressed in erythroid cells expanded from polycythemia vera patients. Blood. 2011; 118:425-436.

46. Vazquez-Tello A, Halwani R, Hamid Q, Al-Muhsen S. Glucocorticoid receptor-beta up-regulation and steroid resistance induction by IL-17 and IL-23 cytokine stimulation in peripheral mononuclear cells. J Clin Immunol. 2013; 33:466-478.

47. Heine VM, Priller M, Ling J, Rowitch DH, Schuller U. Dexamethasone destabilizes Nmyc to inhibit the growth of hedgehog-associated medulloblastoma. Cancer Res. 2010; 70:5220-5225.
48. Kudawara I, Ueda T, Yoshikawa H, Miyama T, Yamamoto T, Nishizawa Y. In vivo inhibition of tumour growth by dexamethasone in murine osteosarcomas. Eur $\mathrm{J}$ Cancer. 2001; 37:1703-1708.

49. Yamamoto T, Nishiguchi M, Inoue N, Goto HG, Kudawara I, Ueda T, Yoshikawa H, Tanigaki Y, Nishizawa Y. Inhibition of murine osteosarcoma cell proliferation by glucocorticoid. Anticancer Res. 2002; 22:4151-4156.

50. Greenberg AK, Hu J, Basu S, Hay J, Reibman J, Yie TA, Tchou-Wong KM, Rom WN, Lee TC. Glucocorticoids inhibit lung cancer cell growth through both the extracellular signal-related kinase pathway and cell cycle regulators. Am J Respir Cell Mol Biol. 2002; 27:320-328.

51. Hofmann J, Kaiser U, Maasberg M, Havemann K. Glucocorticoid receptors and growth inhibitory effects of dexamethasone in human lung cancer cell lines. Eur J Cancer. 1995; 31A:2053-2058.

52. Fauconnet S, Bernardini S, Lascombe I, Boiteux G, Clairotte A, Monnien F, Chabannes E, Bittard H. Expression analysis of VEGF-A and VEGF-B: relationship with clinicopathological parameters in bladder cancer. Oncol Rep. 2009; 21:1495-1504.

53. Hinds TD, Peck B, Shek E, Stroup S, Hinson J, Arthur S, Marino JS. Overexpression of Glucocorticoid Receptor beta Enhances Myogenesis and Reduces Catabolic Gene Expression. Int J Mol Sci. 2016; 17.

54. Metalli D, Lovat F, Tripodi F, Genua M, Xu SQ, Spinelli M, Alberghina L, Vanoni M, Baffa R, Gomella LG, Iozzo RV, Morrione A. The insulin-like growth factor receptor I promotes motility and invasion of bladder cancer cells through Akt- and mitogen-activated protein kinase-dependent activation of paxillin. Am J Pathol. 2010; 176:2997-3006.

55. Newton CC, Gapstur SM, Campbell PT, Jacobs EJ. Type 2 diabetes mellitus, insulin-use and risk of bladder cancer in a large cohort study. Int J Cancer. 2013; 132:2186-2191.

56. Hsiao FY, Hsieh PH, Huang WF, Tsai YW, Gau CS. Risk of bladder cancer in diabetic patients treated with rosiglitazone or pioglitazone: a nested case-control study. Drug safety. 2013; 36:643-649.

57. Lewis JD, Ferrara A, Peng T, Hedderson M, Bilker WB, Quesenberry CP, Jr., Vaughn DJ, Nessel L, Selby J, Strom BL. Risk of bladder cancer among diabetic patients treated with pioglitazone: interim report of a longitudinal cohort study. Diabetes care. 2011; 34:916-922.

58. Ligr M, Li Y, Logan SK, Taneja S, Melamed J, Lepor H, Garabedian MJ, Lee P. Mifepristone inhibits GRbeta coupled prostate cancer cell proliferation. J Urol. 2012; 188:981-988. 